Document downloaded from:

http://hdl.handle.net/10251/122505

This paper must be cited as:

Doménech Carbó, A.; Domenech Carbo, MT.; Redondo-Marugán, J.; Osete Cortina, L.; Vivancos Ramón, MV.; Martínez, B.; Martínez Lázaro, ID.... (2018). Electrochemical Characterization and Dating of Archaeological Leaded Bronze Objects Using the Voltammetry of Immobilized Particles. Archaeometry. 60(2):308-324.

https://doi.org/10.1111/arcm.12308

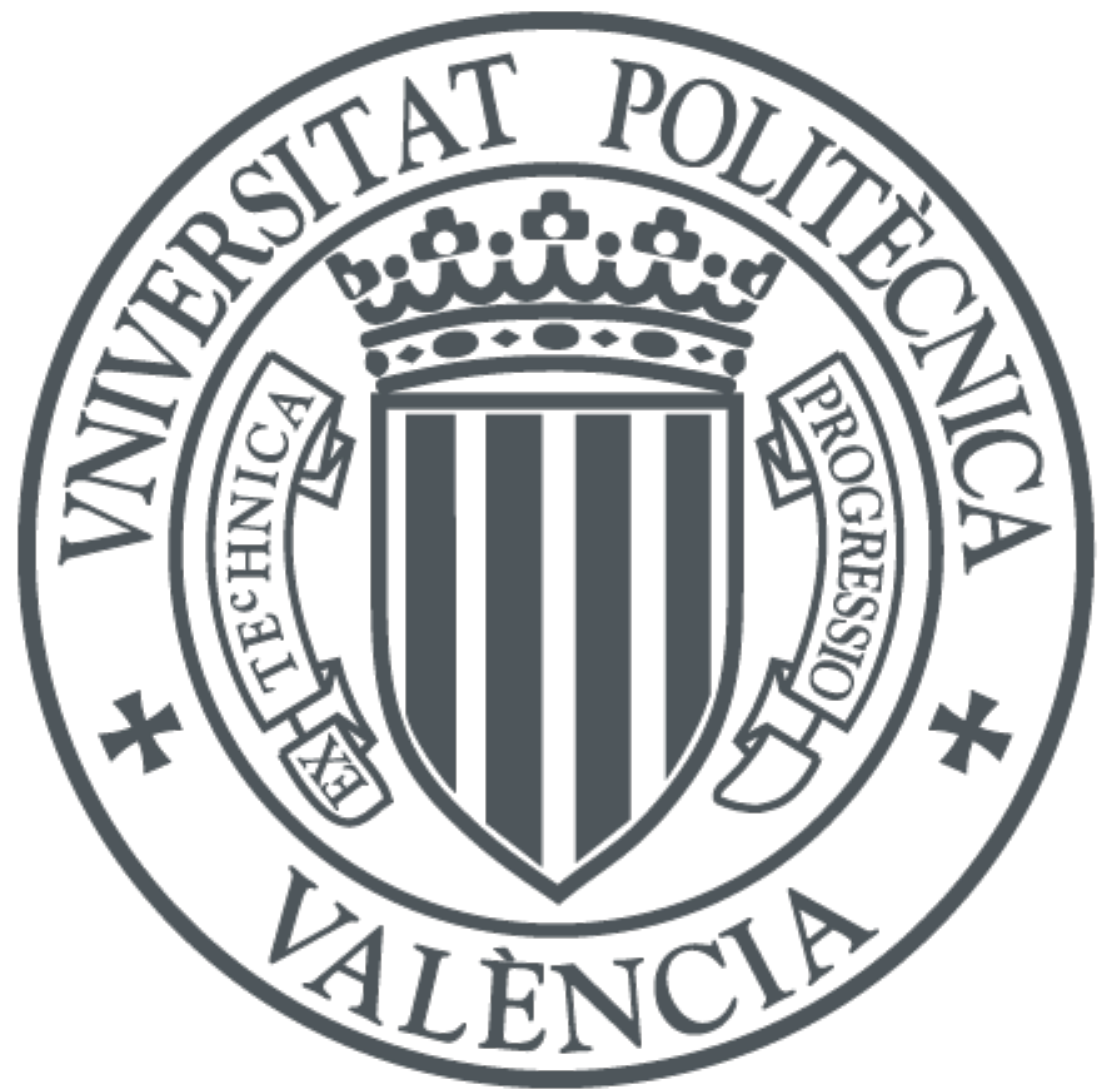

The final publication is available at http://doi.org/10.1111/arcm.12308

Copyright Blackwell Publishing Additional Information 
See discussions, stats, and author profiles for this publication at: https://www.researchgate.net/publication/316298804

\section{Electrochemical Characterization and Dating of Archaeological Leaded Bronze Objects Using the Voltammetry of Immobilized Particles: Archaeological leaded bronze objects and voltamm...}

Article in Archaeometry · April 2017

DOI: 10.1111/arcm.12308

\section{CITATIONS}

3

11 authors, including:

Antonio Domènech

University of Valencia

377 PUBLICATIONS 5,387 CITATIONS

SEE PROFILE

Jorge Redondo

Universitat Politècnica de València

4 PUBLICATIONS 25 CITATIONS

SEE PROFILE
READS

151

María Teresa Doménech-Carbó

Universitat Politècnica de València 183 PUBlicATIONS 3,008 CITATIONS

SEE PROFILE

Wassef Sekhaneh

Yarmouk University

25 PUblications 108 Citations

SEE PROFILE

Some of the authors of this publication are also working on these related projects:

Project Yag-laser in archaeology View project

Project Algal Biodeteriorioration View project 


\title{
ELECTROCHEMICAL CHARACTERIZATION AND DATING OF ARCHAEOLOGICAL LEADED BRONZE OBJECTS USING THE VOLTAMMETRY OF IMMOBILIZED PARTICLES*
}

\section{A. DOMÉNECH-CARBÓ†}

Departament de Química Analítica, Universitat de València, Dr Moliner 5046100 Burjassot, València, Spain

M. T. DOMÉNECH-CARBÓ, J. REDONDO-MARUGÁN, L. OSETE-CORTINA, M. V. VIVANCOSRAMÓN, B. MARTIINEZ and I. MARTÍNEZ-LÁZARO

Institut de Restauració del Patrimoni, Universitat Politècnica de València, Camino de Vera 1446022

València, Spain

J. BARRIO and Á. FUENTES

Departamento de Prehistoria y Arqueología, Universidad Autónoma de Madrid, Avd. Tomás y Valiente 1 28049 Madrid, Spain

W. AL SEKKANEH

Faculty of Archaeology and Anthropology, Yarmouk University, Irbid, Jordan and T. PASÍES

Museu de Prehistòria de València, Corona 3646003 Valencia, Spain

\begin{abstract}
The application of solid state electrochemistry techniques for the characterization and dating of leaded bronze objects is described. Characteristic voltammetric signatures of copper and lead corrosion products were used as markers of more or less prolonged corrosion periods. The proposed methodology was applied to samples from the Roman archaeological sites of Valeria (Spain) and lGadara (Jordan), Roman and medieval sites in Xàtiva (Spain), and modern statuary exhibited outdoors, on the campus of the Universitat Politècnica of Valencia, Spain, covering a time interval between the fourth to second century BC and the 20th century $A D$. For such samples, the ratio between the signals for copper and lead corrosion products decreased monotonically with the corrosion time. This variation was modelled on the basis of thermochemical and kinetic considerations, the experimental data being consistent with a potential rate law for the corrosion process.
\end{abstract}

KEYWORDS: LEADED BRONZE, VOLTAMMETRY OF IMMOBILIZED PARTICLES, TAFEL ANALYSIS, DATING

\section{INTRODUCTION}

The identification of the constitutive materials of archaeological metal objects and their dating are classical analytical demands for archaeologists, conservators and restorers (Pernicka 1998; Scott 2002). The tracing of the provenance of the materials can be derived from the chemical composition of the alloy, isotope ratios, and the microstructure of the alloy and patina from metallographic cross-sections (Attanasio et al. 2001; Constantinides et al. 2002). Since sampling the metal core is in general not allowed for archaeological objects, the characterization of the metallic material, its provenance, its manufacturing technique and its

*Received 2 May 2016; accepted 21 December 2016

†Corresponding author: email antonio.domenech@uv.es

(C) 2017 University of Oxford 
situation within a defined chronological context have to be obtained from the physicochemical properties of the metal surface products (Scott 1994; Robbiola et al. 1998; Robbiola Q2 and Portier 1998, 2006; Sandu et al. 2006). Thus, the relation between the $\mathrm{Zn} / \mathrm{Cu}$ and $\mathrm{Sn} / \mathrm{Cu}$ concentrations in the patina and the base alloy have been proposed as chronological indicators for brass and bronze artefacts (Robbiola and Hurtel 1997; Welter 2003) based on decuprification, destannification and dezincation, which are widely extended phenomena in bronze corrosion (Weisser 1975; Meeks 1986; Leoni et al. 1991; Scott 1994; Robbiola and Hurtel 1997; Robbiola et al. 1998; Chiavari et al. 2007; Robbiola and Portier 1998; De Ryck et al. 2003; Welter 2003).

A variety of spectroscopic, diffraction and microscopy techniques have been used for characterizing the composition of metal patinas (Constantinides et al. 2002; Selwyn 2004; Chiavari et al. 2007; Cura D'Ars de Figueiredo et al. 2007). In this context, the voltammetry of immobilized particles (VIMP), a solid-state electrochemical methodology developed by Q3 Scholz and Meyer (1998) and Scholz et al. (2014), which provides analytical information on a variety of sparingly soluble solids (Doménech-Carbó et al. 2013), has been applied in the archaeological domain (Doménech-Carbó et al. 2009; Doménech-Carbó 2010) complementing well-established spectroscopic, diffraction and electron microscopy techniques. The application of VIMP for identifying metals and alloys (Costa and Urban 2005; Costa et al. 2010; Ottenwelter and Costa 2015) and the metal corrosion products (Souissi et al. 2004; Serghini-Idrissi et al. 2005; Doménech-Carbó et al. 2008; Satovic et al. 2010) has been described, also including quantitation (Arjmand and Adriaens 2012) and layer-by-layer analysis (Doménech-Carbó et al. 2010). Exploiting the possibility of 'one-touch' sampling strategies based on 'graphite pencil' electrodes (Blum et al. 1996; Doménech-Carbó et al. 2011b), electrochemical data have previously been used for authentication of lead (Doménech-Carbó et al. 2011d, 2015) and the dating of lead (Doménech-Carbó et al. 2011a, 2012b) and bronze (Doménech-Carbó et al. 2014, 2016b).

In a previous paper (Doménech-Carbó et al. 2016a), we described the application of the VIMP technique for characterizing the corrosion patterns of modern leaded bronze statuary using Tafel analysis of voltammetric curves. The practice of preparing leaded bronze has been known since antiquity (Hughes et al. 1982). This addition lowers the cost of the alloy and results in an improved fluidity and mould-filling capability without affecting the structures after solidification. The relatively low solubility of lead in copper results, however, in the appearance of peculiar globular features and corrosion patterns (Gettens 1969; Meeks 1986; Chase 1994; Ingo et al. 2006), including the presence of unalloyed copper inclusions, which have been attributed to a pseudomorphic replacement process associated with destannification (Leoni et al. 1991) and the redeposition of copper in spaces left by lead oxidation and dissolution (McCann et al. 1999; Quaranta et al. 2014).

Here, the application of the VIMP methodology is described for the characterization and dating of leaded bronze. It is pertinent to note that, in line with Meeks (1986), this approach has two fundamental limitations, strictly speaking: an exact knowledge of the composition and element distribution of the base metal and the corrosion layers and of the casting, cold working and so on carried out in the fabrication of the object is necessary for the above purposes because there is a potential high variability in the composition, fabrication technique and 'corrosion history' of the studied pieces. Unfortunately, acquisition of much of the above archaeometric information requires the use of destructive sampling, which is in general not accessible (Scott 1994; Robbiola et al. 1998; Robbiola and Portier 1998, 2006; Sandu et al. 2006). The purpose of the current work-in spite of the aforementioned limitations-was an attempt to obtain 
analytical information using non-invasive sampling limited to the corrosion layers, which was potentially applicable to samples having compositions and a 'corrosion history' that can be assumed to be relatively similar.

The voltammetric data are complemented by attenuated total reflectance - Fourier transform infrared spectroscopy (ATR-FTIR) and field emission scanning electron microscopy with energy-dispersive X-ray microanalysis (FESEM-EDX). The study was carried out on leaded bronze samples from various provenances, including a sculpture from the Roman city of Valeria (Cuenca, Spain, second half of the first century AD), a set of weights from the site of Gadara (Jordan), dated to the fourth century AD, various objects from archaeological sites in Xàtiva (Valencia, Spain) and three modern sculptures from the statuary exhibited outdoors on the campus of the Universitat Politècnica of Valencia (Spain). The provenance, conservation condition and age of the samples are summarized in Table 1. In all cases, samples were taken T1 from objects that exhibited surfaces with a high degree of homogeneity in the smooth, plane or smoothly curved regions, often accompanied by localized pitting corrosion and deposits of powdered corrosion materials in the corners (robe folds etc.). Descriptions of the archaeological contexts of the Valeria samples are available in Fuentes and Escobar (2013) and Donate Carretero et al. (2015).

Table 1 The samples from leaded bronze sculptures and objects discussed in this study

\begin{tabular}{|c|c|c|}
\hline Sample & Description of the object & Provenance \\
\hline $\begin{array}{l}\text { MP-1-1 to } \\
\text { MP-1-3 }\end{array}$ & $\begin{array}{l}\text { Votive figurine; dark green surface, apparently homogeneous } \\
\text { with greenish localized regions in corners }\end{array}$ & $\begin{array}{l}\text { Iberian site (Despeñaperros, Jaén), } \\
\text { fourth to second century } \mathrm{BC}^{*}\end{array}$ \\
\hline $\mathrm{V}-122-1$ to & Fragment 1 of sculpture, dark grey surface with greenish & Valeria site, second half of the first \\
\hline $\mathrm{V}-122-3$ & localized regions & century $\mathrm{AD}^{\dagger}$ \\
\hline V-390-1 to & Fragment 2 of sculpture, dark grey surface with greenish & Valeria site, second half of the first \\
\hline V-390-3 & localized regions & century $\mathrm{AD}^{\dagger}$ \\
\hline $\begin{array}{l}\text { VI-1-1 and } \\
\text { VI-1-2 }\end{array}$ & $\begin{array}{l}\text { Fibulae, dark green surface, apparently homogeneous, with } \\
\text { greenish pitting and localized regions in corners }\end{array}$ & $\begin{array}{l}\text { El Viveret site, first to second century } \\
\qquad \mathrm{AD}^{\ddagger}\end{array}$ \\
\hline $\begin{array}{l}\mathrm{G}-1-1 \text { to } \mathrm{G}- \\
1-4\end{array}$ & $\begin{array}{c}\text { Pieces } 1-4 \text { of a set of weights, black surfaces with high } \\
\text { homogeneity }\end{array}$ & Gadara site, fourth century $\mathrm{AD}^{\S}$ \\
\hline $\mathrm{X}-1$ & $\begin{array}{c}\text { Fragment of spur (Caliphal period), dark green surface with } \\
\text { greenish localized regions in corners }\end{array}$ & Xàtiva (Valencia), AD 950 \\
\hline $\begin{array}{l}\text { MP-2-1 to } \\
\text { MP-2-3 }\end{array}$ & $\begin{array}{l}\text { Buckle, black surfaces with high homogeneity but with several } \\
\text { localized greenish pits }\end{array}$ & $\begin{array}{l}\text { San Cristóbal church (Picassent), } \\
18 \text { th-19th century } \mathrm{AD}^{*}\end{array}$ \\
\hline UPV-1 & Gades, la dança, dark grey surface apparently homogeneous ${ }^{\mathrm{gI}}$ & Sculpture by Antonio Miró, 2001" \\
\hline UPV-2 & Crónica del viento, dark grey surface apparently homogeneous $\mathrm{s}^{\mathrm{II}}$ & Sculpture by Martín Chirino, $1991^{\|}$ \\
\hline UPV-3 & Unidad yunta, dark grey surface apparently homogeneous ${ }^{\mathrm{II}}$ & Sculpture by Pablo Serrano, $1970^{\|}$ \\
\hline
\end{tabular}

\footnotetext{
*Museu de Prehistòria de València, Spain.

Universidad Autónoma de Madrid, Spain.

${ }^{*}$ Museu Municipal of Xàtiva, Spain.

${ }^{\S}$ Yarmouk University, Irbid, Jordan.

${ }^{\mathrm{I}}$ Data for these sculptures correspond to the air-exposed regions; regions near the soil showed localized corrosion (see DoménechCarbó et al. 2016a).

"Campus of the Universitat Politècnica of Valencia, Spain.
} 
Doménech-Carbó A. et al.

EXPERIMENTAL

\section{Instrumentation and procedures}

Electrochemical experiments were performed at $298 \pm 1 \mathrm{~K}$ using a $\mathrm{CH} 920$ c device (Cambria Scientific, UK) with a Pt auxiliary electrode and an $\mathrm{AgCl}(3 \mathrm{M} \mathrm{NaCl}) / \mathrm{Ag}$ reference electrode, using an aqueous sodium acetate buffer (HAc/NaAc, Panreac) as a supporting electrolyte, previously degasified by bubbling Ar for $10 \mathrm{~min}$. The powdered reference materials and samples were abrasively attached to paraffin-impregnated graphite bars (Staedtler HB, and Faber Castell TK 9071, diameter $2.0 \mathrm{~mm}, 68 \mathrm{wt} \%$ graphite), following the conventional VIMP protocols (Scholz and Meyer 1998; Scholz et al. 2014).

The IR spectra of the samples, acquired in the ATR mode, were obtained using a Vertex 70 (Bruker Optik GmbH, Germany) Fourier transform infrared spectrometer with a fast-recovery deuterated triglycine sulphate (FR-DTGS) temperature-stabilized coated detector and a MKII Golden Gate attenuated total reflectance (ATR) accessory. A total of 32 scans were collected at a resolution of $4 \mathrm{~cm}^{-1}$ and the spectra were processed using the OPUS 5.0/IR software (Bruker Optik GmbH, Germany).

Field emission scanning electron microscopy X-ray microanalysis (FESEM) was carried out using a Zeiss model ULTRA 55 field emission scanning electron microscope, operating with an Oxford-X Max X-ray microanalysis system. Image acquisition was done at an accelerating voltage of $3 \mathrm{kV}$. The samples were examined under a Zeiss model ULTRA 55 field emission scanning electron microscope, operating with an Oxford-X Max X-ray microanalysis system. Image acquisition was done at an accelerating voltage of $3 \mathrm{kV}$. The chemical compositions of the minerals were obtained at an accelerating voltage of $20 \mathrm{kV}$ and the working distance for the X-ray detector was 6-7 mm.

\section{Reference materials and samples}

The reference materials were $\mathrm{Cu}_{2} \mathrm{O}$ (cuprite), $\mathrm{CuO}$ (tenorite), $\mathrm{PbO}$ (litharge), $\mathrm{PbO}_{2}$ (plattnerite), $\mathrm{PbSO}_{4}$ (anglesite), $\mathrm{PbCO}_{3}$ (cerussite) and $\mathrm{PbCl}_{2}$ (cotunnite), all Merck reagents, accompanied by $2 \mathrm{PbCO}_{3} \cdot \mathrm{Pb}(\mathrm{OH})_{2}$ (synthetic hydrocerussite, Sigma-Aldrich) and $\mathrm{CuCl}$ (De Haën). Azurite (K10200) and malachite (K10300) were supplied by Kremer pigments, whereas brochantite and various copper trihydroxychlorides (atacamite, clinoatacamite) were prepared by means of recommended procedures (Scott 2000). Identification of corrosion products was carried out based on the VIMP and ATR-FTIR data of reference materials described in the literature (Scott 2000; Bouchard and Smith 2003; Frost 2003; Selwyn 2004) and previous papers (Doménech-Carbó et al. 2011b, 2014, 2016a). Previously studied UPV metal samples, for which the composition of the base alloy was known, were taken as reference leaded bronze materials. Pertinent analytical data can be seen in Doménech-Carbó et al. (2016).

All of the studied objects and sculptures showed dark grey/dark green surfaces with apparently high hue and texture homogeneity in the plane or smoothly curved regions, accompanied by localized pitting corrosion and deposits of powdered corrosion materials in the corners (robe folds etc.). Sampling was performed by pressing the graphite electrodes on to the uniform regions of the surface of the various objects, using the 'one-touch' protocol. The number of samples taken from each object or sculpture varied between three and five, depending on the available surface area. The criteria for the location of the sampling were: (i) regions of more or less different hue and/or texture but homogeneous appearance; (ii) the absence of gross corrosion features (powdered materials in surface, cracks and crevices). Note that the sampling area was 
$\sim 2 \mathrm{~mm}$ in diameter, so that inhomogeneities at the micrometre scale were averaged. Due to the low hardness of graphite, the sampling procedure does not produce any macroscopic damage on the surface of the artefact, leaving only a graphite powder mark that can easily be removed with a smooth brush. In cases where the surface of the object contained any region with powdered corrosion materials, additional samples were studied by taking an amount of $\sim 1 \mu \mathrm{g}$ of the corrosion products and processing it via conventional abrasive transference (Scholz et al. 2014), aided by an agate mortar and pestle. It is pertinent to remark that sampling was carried out at the various museums (see Table 1) and that the sample-modified graphite bars were later transported to Valencia (Spain), where the voltammetric measurements were performed. The composition of the uncorroded bronze bulk could not be obtained, because the necessary penetrating assays were not allowed by the corresponding institutions. Table 1 summarizes the provenance and characteristics of the studied samples. The archaeological context of the samples from Valeria has been reported by Fuentes and Escobar (2013) and Donate Carretero et al. (2015).

\section{RESULTS AND DISCUSSION}

\section{The voltammetric pattern}

Figures 1 (a) and 1 (b) show the squarewave voltammetric responses of sample MP-2-2 from a F1 buckle dated to the 18th-19th century $\mathrm{AD}$, attached to a graphite electrode immersed in a $0.25 \mathrm{M} \mathrm{HAc} / \mathrm{NaAc}$ aqueous solution at $\mathrm{pH} 4.75$. This sample displayed voltammetric features similar to those of 20th-century UPV samples, consisting of cathodic peaks at $-0.10 \mathrm{~V}\left(\mathrm{C}_{1}\right)$ and $-0.55 \mathrm{~V}\left(\mathrm{C}_{2}\right)$ and oxidation peaks at $-0.45 \mathrm{~V}\left(\mathrm{~A}_{2}\right)$ and $0.00 \mathrm{~V}\left(\mathrm{~A}_{1}\right)$. On the basis of an abundant literature on the electrochemistry of copper and lead corrosion products (DoménechCarbó et al. 2016a and references herein), the peak $\mathrm{C}_{1}$ can be attributed to the reduction of cuprite, usually forming the primary patina of copper corrosion (Robbiola et al. 1998) and frequently accompanied by minerals of the brochantite type and/or malachite and/or atacamite types. The peak $\mathrm{C}_{2}$ corresponds to the reduction of lead corrosion products, where litharge $(\mathrm{PbO})$ usually forms the primary patina. The representative electrochemical processes are as follows:

$$
\begin{aligned}
& \mathrm{Cu}_{2} \mathrm{O}(\text { solid })+2 \mathrm{H}^{+}(\mathrm{aq})+2 \mathrm{e}^{-} \rightarrow \mathrm{Cu}(\text { solid })+\mathrm{H}_{2} \mathrm{O}, \\
& \mathrm{PbO}(\text { solid })+2 \mathrm{H}^{+}(\mathrm{aq})+2 \mathrm{e}^{-} \rightarrow \mathrm{Pb}(\text { solid })+\mathrm{H}_{2} \mathrm{O} .
\end{aligned}
$$

In turn, the processes $A_{1}$ and $A_{2}$ correspond to the well-known oxidative dissolution of copper and lead metal oxides, respectively.

Figures 1 (c) and 1 (d) depict the voltammograms for sample X-1 from a spur (Caliphal period, 10 th century $\mathrm{AD})$. Here, additional cathodic signals at $-0.45 \mathrm{~V}\left(\mathrm{C}_{3}\right)$ and $+0.65 \mathrm{~V}\left(\mathrm{C}_{4}\right)$ and a shoulder between $-0.75 \mathrm{~V}$ and $-0.95 \mathrm{~V}\left(\mathrm{C}_{5}\right)$ appeared. Such additional signals appeared, although with differing intensities, in all 'ancient' samples, as can be seen in Figures 2 (a) and F2 2 (b) for samples G-1-1 (Gadara site, fourth century AD) and V-1-3 (Valeria site, first century $\mathrm{AD})$. Based on literature data, these signals can be attributed, respectively, to the reduction of Sn(II) species (Doménech-Carbó and Doménech-Carbó 2005) and/or tenorite (Doménech-Carbó et al. 2014, 2016a) $\left(\mathrm{C}_{3}\right)$, plattnerite $\left(\mathrm{PbO}_{2}, \mathrm{C}_{4}\right)$ (Pavlov et al. 1989, 1991; Cai et al. 1995; Zakharchuk et al. 2000; Doménech-Carbó et al. 2011b,d) and porous PbO generated as a result 


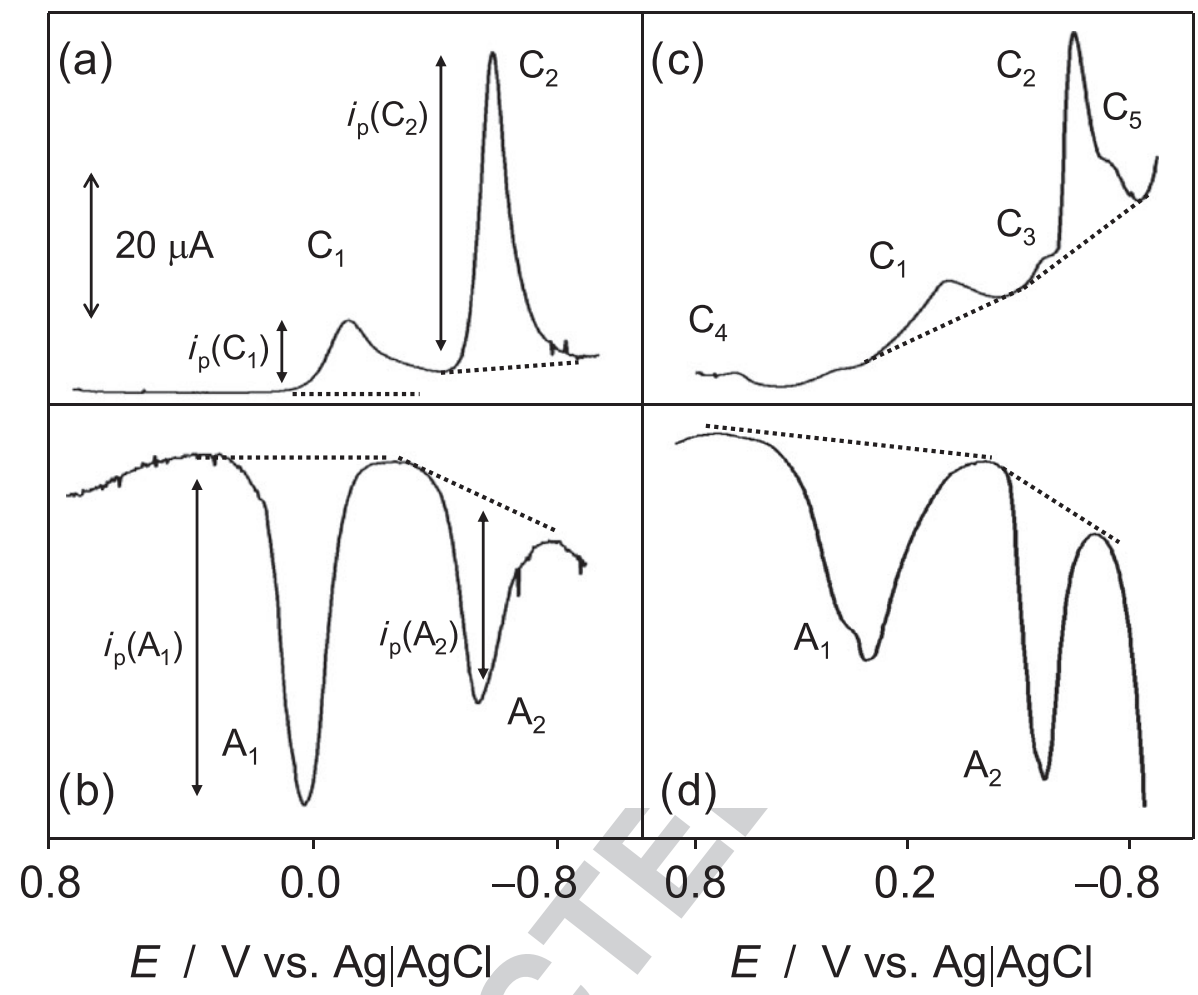

Figure 1 Squarewave voltammograms of samples ( $a, b)$ MP-2-2 from a buckle (18th-19th century AD), and (c, d) X-1 from a spur (10th century $A D$ ) attached to a graphite electrode immersed in a $0.25 \mathrm{MHAc/NaAc}$ aqueous solution at $p H 4.75$. Potential scan initiated at $(a, c)+0.85 \mathrm{~V}$ in the negative direction and $(b, d)-0.85 \mathrm{~V}$ in the positive direction; potential step increment $4 \mathrm{mV}$; squarewave amplitude $25 \mathrm{mV}$; frequency $5 \mathrm{~Hz}$. The baselines used for measuring peak currents are depicted as dotted lines.

of the alteration of the primary patina of litharge (Pavlov et al. 1989, 1991; Cai et al. 1995) $\left(\mathrm{C}_{5}\right)$. As previously noted (Doménech-Carbó et al. 2011a,d), the peak $\mathrm{C}_{4}$, although weak, was well defined in samples submitted to prolonged corrosion but absent in samples from the 18th-20th century (Fig. 2 (c)).

The first aspect to be underlined in the recorded voltammograms is that, in general, the leadbased voltammetric signals were more intense than the copper-based ones, both in the negativeand in the positive-going potential scans. This feature is in agreement with the major corrosivity of lead expected on the basis of the values of the standard electrode potentials for the various $\mathrm{Pb}(\mathrm{II}) / \mathrm{Pb}(0)$ and $\mathrm{Cu}(\mathrm{II}) / \mathrm{Cu}(0)$ couples (see below). Also in agreement with those expectations, the ratio between the peak currents $\left(i_{\mathrm{p}}\right)$ for processes $\mathrm{C}_{1}$ (reduction of copper corrosion products) and $\mathrm{C}_{2}$ (reduction of lead corrosion products), $i_{\mathrm{p}}\left(\mathrm{C}_{1}\right) / i_{\mathrm{p}}\left(\mathrm{C}_{2}\right)$, appeared to decrease on increasing the corrosion time. This can be seen on comparing the voltammograms for sample MP-2-2 (Fig. 1 (a)) with those in Figures 1 (c), 2 (a) and 2 (b). Similar reasoning applies to the ratio between the peak currents of the processes $\mathrm{A}_{1}$ and $\mathrm{A}_{2}, i_{\mathrm{p}}\left(\mathrm{A}_{1}\right) / i_{\mathrm{p}}\left(\mathrm{A}_{2}\right)$.

A relevant question, however, was to what extent the voltammetric data were representative of the whole objects. For this reason, sampling was performed on between three and five differing points of each object, selecting areas of apparently homogeneous texture and hue. The deviations in the measured values of the $i_{\mathrm{p}}\left(\mathrm{C}_{1}\right) / i_{\mathrm{p}}\left(\mathrm{C}_{2}\right)$ and $i_{\mathrm{p}}\left(\mathrm{A}_{1}\right) / i_{\mathrm{p}}\left(\mathrm{A}_{2}\right)$ ratios for each object were typically 


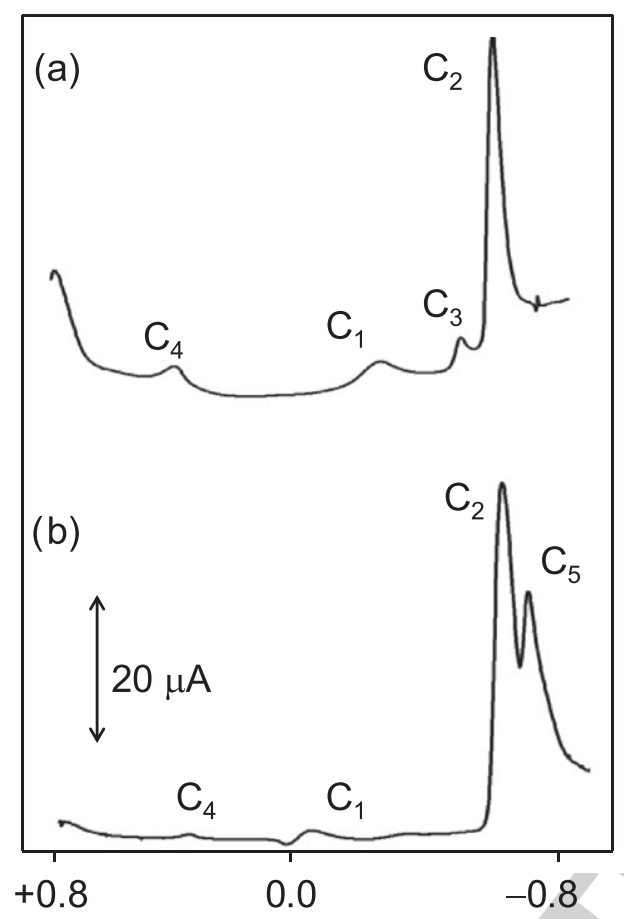

E / V vs. Ag|AgCl

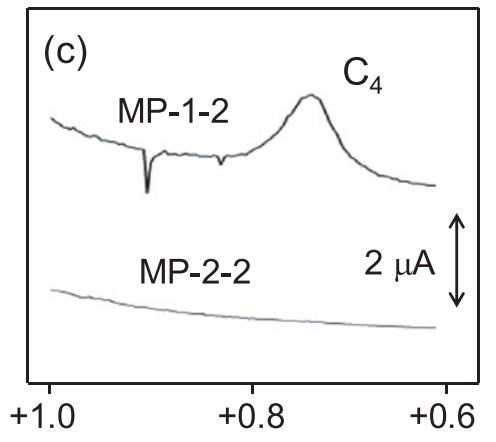

E / V vs. Ag|AgCl

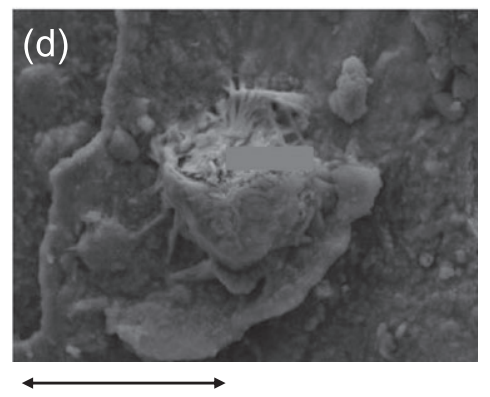

$20 \mu \mathrm{m}$

Figure 2 Squarewave voltammograms of samples (a) G-1-1 from the site of Gadara (fourth century AD) and (b) V-1-3 from the site of Valeria (first century $A D$ ); (c) a detail of the region of peak $C_{4}$ in the squarewave voltammograms of samples MP-1-2 (fourth to second century BC) and MP-2-2 (18th-19th century AD); and (d) a FESEM image of sample $U P V-2$.

within $5-10 \%$, in a few cases reaching a maximum deviation of $25 \%$ between them. Since the differences of the values of such ratios between recent and 'ancient' objects were larger than $400 \%$ (see below), it appeared reasonable to consider the above ratios as representative of aging.

It was conceivable that segregation of lead, a typical feature of leaded bronze (Meeks 1986; Ingo et al. 2006; Cura D'Ars de Figueiredo et al. 2007), produced heterogeneities lowering the representativity of the VIMP measurements. However, although lead segregation forming noduli can occur even in 'modern' sculptures, as can be seen in Figure 2 (d), the intensity of the coppercentred signals relative to the lead-centred ones varied from 'old' to 'modern' objects, as previously noted. This can be attributed to the fact that the region sampled for electrochemical measurements (an electrode area of $2 \mathrm{~mm}$ diameter) was clearly larger than the size of the lead noduli (typically $10 \mu \mathrm{m}$; Fig. 2 (d)).

The application of Tafel analysis (Doménech-Carbó et al. 2008, 2010, 2011b, 2016a) to signals $\mathrm{C}_{1}$ and $\mathrm{C}_{2}$ indicated that cuprite, often accompanied by malachite or minerals of the atacamite group, was the main copper corrosion product, whereas litharge $(\mathrm{PbO})$, accompanied by anglesite $\left(\mathrm{PbSO}_{4}\right)$ in the case of the Valeria samples, was the predominant lead corrosion product. These data were consistent with the composition of the powdered materials extracted from localized highly corroded regions of samples UPV, G and V, determined by both VIMP and ATR-FTIR spectroscopy. In particular, the presence of anglesite was denoted by 
characteristic infrared bands at 605, 642, 979 and $1057 \mathrm{~cm}^{-1}$ (Bouchard and Smith 2003; Frost 2003). The presence of anglesite is not usual in the archaeological context (Selwyn 2004) and suggested the possibility of an artificial patination using sulphur or any sulphur compound performed at origin. This hypothesis is in agreement with the recognized attempts in the Roman statuary to mimic Greek statuary (Formigli et al. 2005, 2006; Donate Carretero et al. 2015).

\section{Electrochemical age criteria}

As described in preceding sections, the studied samples corresponded to regions of apparently homogeneous smooth corrosion of lead bronze artefacts. Then, assuming that the composition and corrosion processes were similar for all pieces, the presence of large $C_{2} / C_{1}$ peak current ratios can be considered as a diagnostic criterion suggesting relatively prolonged corrosion (see below). Additional criteria can be derived taking into account that both the aerobic oxidation of $\mathrm{PbO}$ to $\mathrm{PbO}_{2}\left(\Delta G_{\mathrm{f}}^{\mathrm{o}}(\mathrm{PbO})=-187.9 \mathrm{~kJ} / \mathrm{mol} ; \Delta G_{\mathrm{f}}^{\mathrm{o}}\left(\mathrm{PbO}_{2}\right)=-217.3 \mathrm{~kJ} / \mathrm{mol}\right)$ and of cuprite to tenorite $\left(\Delta G_{\mathrm{f}}^{\mathrm{o}} \quad\left(\mathrm{Cu}_{2} \mathrm{O}\right)=-146 \mathrm{~kJ} / \mathrm{mol} ; \Delta G_{\mathrm{f}}^{\mathrm{o}} \quad(\mathrm{CuO})=-130 \mathrm{~kJ} / \mathrm{mol}\right)$ (Nair et al. 1999) are thermodynamically spontaneous processes, but they occur at a low reaction rate under ordinary corrosion conditions. Accordingly, it is reasonable to expect that under prolonged contact with oxidizing atmospheric conditions, the amounts of $\mathrm{PbO}_{2}$ and $\mathrm{CuO}$ should increase relative to the primary corrosion products, $\mathrm{Cu}_{2} \mathrm{O}$ and $\mathrm{PbO}$, progressively. Then, the appearance of peak $\mathrm{C}_{4}$ denoting the presence of plattnerite can be considered as indicative of prolonged lead corrosion (Doménech-Carbó et al. 2011a,b,d). Identical considerations apply to the appearance of a relatively intense signal of tenorite reduction $\left(\mathrm{C}_{3}\right)$, because of the aerobic oxidation. This process would be favoured in bronze artefacts due to their contact with a $\mathrm{CO}_{2}$-rich atmosphere, as well as with calcareous materials (Scott 1997). Consistently, the tenorite reduction signal $\mathrm{C}_{3}$ increases relative to the reduction of cuprite $\left(\mathrm{C}_{1}\right)$ in samples submitted to relatively smooth atmospheric corrosion, prompting the use of such signals for dating purposes (Doménech-Carbó et al. 2014, 2015).

As described in earlier papers, the Tafel analysis (Doménech-Carbó et al. 2008, 2010, 2011b) and the modified Tafel analysis (Doménech-Carbó et al. 2011c, 2016a) of the voltammetric curves permitted the identification of copper and lead corrosion products from the slope and the ordinate at the origin (Tafel $S L$ and Tafel $O O$, respectively) of the linear variations of $\ln \left(i / i_{\mathrm{p}}\right)$ versus $E-E_{\mathrm{p}}$ and of $\ln \left[\left(i_{\mathrm{p}}-i\right) / i_{\mathrm{p}}\right]$ versus $\ln \left(E-E_{\mathrm{p}}\right)$ using the values of the current $i$ at a given potential $E$ and the corresponding peak current $\left(i_{\mathrm{p}}\right)$ and peak potential $\left(E_{\mathrm{p}}\right)$ of the voltammetric waves.

Our data for peak $C_{1}$ provided representations with high linearity for both the reference materials and the samples. Figure 3 depicts the representation of Tafel $S L$ versus Tafel $O O$ for F3 the reference materials, represented as error squares, representative of the maximum uncertainty, from five independent replicate experiments such as in Figures 1, 2 (a) and 2 (b). The positions of the data points for brochantite, azurite, malachite, cuprite and atacamite are aligned in the diagonal of the diagram (the 'reference materials region', marked by an ellipse drawn in Fig. 3). The positions of the data points for the Valeria samples (triangles) and sample UPV-1 are distributed around the region of the diagram, the extremes being brochantite and atacamite. Samples in this region display a voltammetric response similar to that of copper corrosion products and mixtures of such products. In turn, samples UPV-2 and UPV-3 (solid triangles) are also placed in the above diagonal, but in the prolongation of the copper(II) trihydroxychloride region (also marked by an ellipse in Fig. 3). This feature suggests, as observed using conventional Tafel analysis (Doménech-Carbó et al. 2016a), that the presence of lead corrosion products modifies the electrochemical parameters for the reduction of those of copper corrosion. 


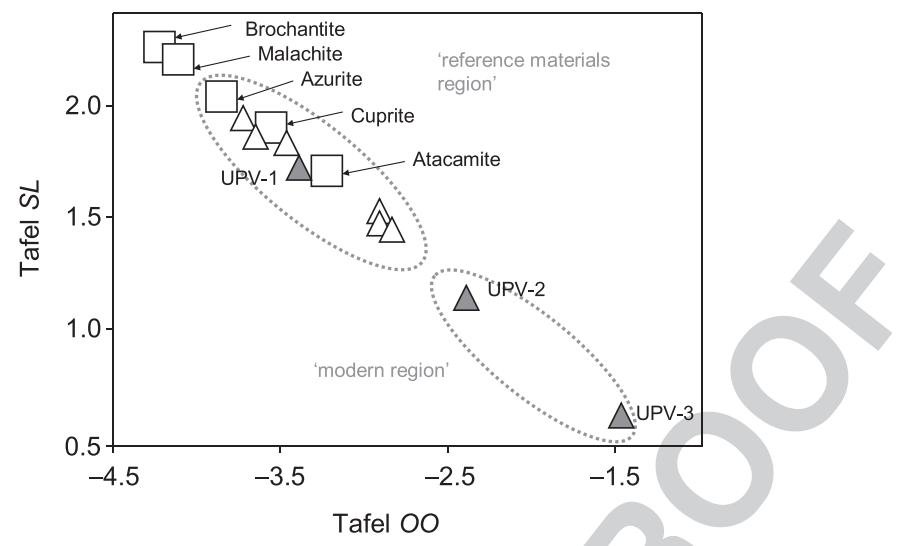

Figure 3 A representation of Tafel SL versus Tafel $O O$ calculated for the $C_{1}$ peak (reduction of copper corrosion products) in voltammograms of reference materials (squares), Gadara and Valeria (triangles) and UPV (solid triangles) from voltammograms in conditions such as in Figures 1 (a), 1 (b), 2 (a) and 2 (b).

The fact that the data points of all 'ancient' samples fall within the region of the reference materials can be interpreted on assuming that, after prolonged corrosion, the corrosion products of copper and lead become mutually disaggregated and produce mutually independent voltammetric responses. This would be also the case for the 'modern' sample UPV-1. In the case of 'modern' samples UPV-2 and UPV-3, the voltammetric response diverges from that of the reference minerals, denoting that the corrosion products of copper and lead remain aggregated, thus mutually influencing their voltammetry (Doménech-Carbó et al. 2016a).

Accordingly, the location of the data points near those of the reference materials in the diagonal of the modified Tafel diagram would be indicative of prolonged corrosion. Obviously, this criterion necessarily has to be handled with caution because 'modern' samples, depending the corrosion conditions, can also produce disaggregated corrosion products the voltammetric response of which falls in the region of the reference materials, as would be the case of sample UPV-1 in Figure 3.

It is pertinent to note that the voltammetric response of the copper and lead corrosion products should be also influenced by the presence of other frequent metallic components such as Sn and $\mathrm{Zn}$. The voltammetric and ATR-FTIR data do not provide evidence of the presence of Sn and $\mathrm{Zn}$ corrosion products (at least, in significant amounts) in the studied samples, a feature consistent with the frequent occurrence of decuprification, destannification and dezincation during the corrosion of bronze (Weisser 1975; Meeks 1986; Leoni et al. 1991; Scott 1994; Robbiola and Hurtel 1997; Robbiola et al. 1998; Chiavari et al. 2007; Robbiola and Portier 1998; De Ryck et al. 2003; Welter 2003).

\section{The dating of leaded bronze artefacts}

As previously noted, the variation of the peak current (or peak area) ratio of the copper- and leadcentred signals in the voltammograms can be taken as a quantitative parameter representative of the composition, corrosion conditions and age of the leaded bronze object. Figure 4 compares the $\mathbf{F} 4$ peak current ratio for samples in this study taking the $i_{\mathrm{p}}\left(\mathrm{C}_{1}\right) / i_{\mathrm{p}}\left(\mathrm{C}_{2}\right)$ ratio ('A') in negative-going scan voltammograms and the $i_{\mathrm{p}}\left(\mathrm{A}_{1}\right) / i_{\mathrm{p}}\left(\mathrm{A}_{2}\right)$ ratio in positive-going scan voltammograms ('B', 'C') for UPV, Valeria and Gadara samples. As previously noted, 'one-touch' sampling on the surface 


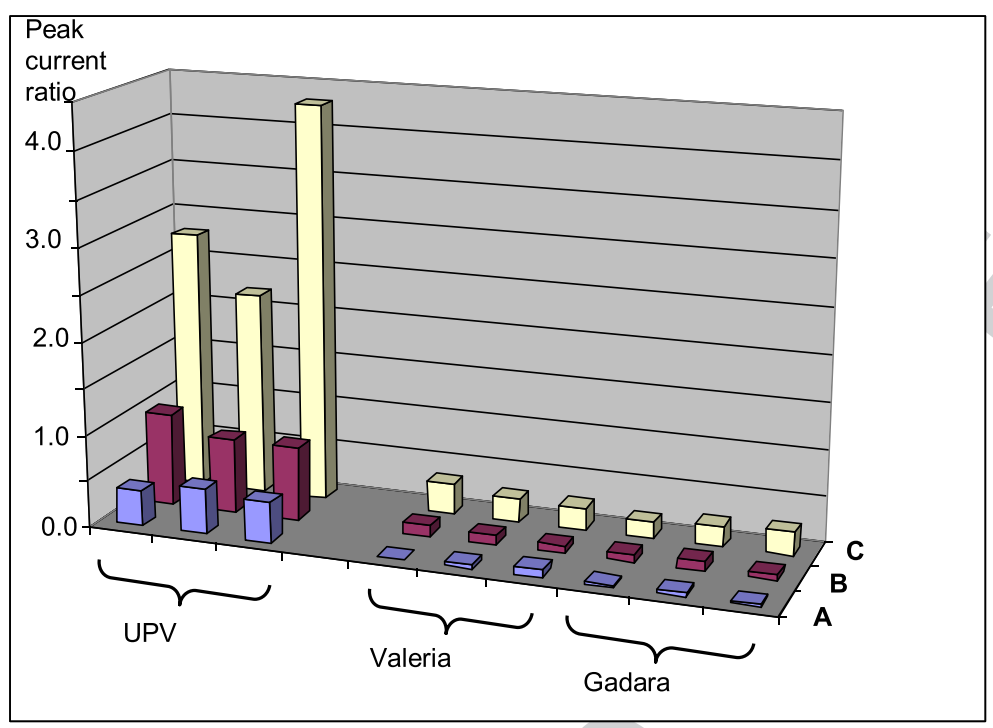

Q5 Figure 4 The variation of the copper signals/lead signals peak current ratio for samples in this study: $A, i_{p}\left(C_{1}\right) / i_{p}\left(C_{2}\right)$ in negative-going scan voltammograms; $B, C, i_{p}\left(A_{1}\right) / i_{p}\left(A_{2}\right)$ in positive-going scan voltammograms for samples taken in the patina (B) and powdered corrosion products $(C)$. [Colour figure can be viewed at wileyonlinelibrary.com]

of the object yields $i_{\mathrm{p}}\left(\mathrm{C}_{1}\right) / i_{\mathrm{p}}\left(\mathrm{C}_{2}\right)$ values for modern UPV samples that are consistently larger (2-4 times) than those of all 'ancient' archaeological samples, as can be seen in Figure 5 (a), where the $\mathbf{F 5}$ variation of the copper-to-lead molar ratio, equivalent to the $i_{\mathrm{p}}\left(\mathrm{C}_{1}\right) / i_{\mathrm{p}}\left(\mathrm{C}_{2}\right)$ ratio on the age of the samples, is depicted. The same result was obtained for the $i_{\mathrm{p}}\left(\mathrm{A}_{1}\right) / i_{\mathrm{p}}\left(\mathrm{A}_{2}\right)$ ratio, which was about 10 times larger for modern leaded bronze sculptures than for Roman-age samples. The same effect was obtained for samples consisting, when available, of powdered corrosion products in localized, highly corroded regions, illustrated for the $i_{\mathrm{p}}\left(\mathrm{A}_{1}\right) / i_{\mathrm{p}}\left(\mathrm{A}_{2}\right)$ ratio in Figure 4 ('C').

A first approach to rationalizing this result can be obtained upon considering the corrosion potentials of lead and copper in leaded bronze. On first examination, one can assume that after very prolonged corrosion under aerobic conditions and treating the metallic samples as a thermodynamically closed system, a limiting situation of thermochemical equilibrium should be established between the base alloy and the corrosion products. This equilibrium can be expressed in terms of a generalized reaction $\mathrm{Pb}+\{$ copper corrosion products $\} \rightarrow \mathrm{Cu}+\{$ lead corrosion products $\}$. Given the standard electrode potentials $E^{\circ}\left(\mathrm{Cu}^{2+} / \mathrm{Cu}\right)=+0.340 \mathrm{~V}$ and $E^{\circ}\left(\mathrm{Pb}^{2+} / \mathrm{Pb}\right)=-0.126 \mathrm{~V}$ (versus $\left.\mathrm{NHE}\right)$, and assuming, for simplicity, that tenorite $(\mathrm{CuO})$ and litharge $(\mathrm{PbO})$ are the corrosion products involved, the equilibrium constant for the above reaction would be given by

$$
\ln K_{\mathrm{eq}}=\frac{n F}{R T}\left(E^{\circ}\left(\mathrm{Cu}^{2+} / \mathrm{Cu}\right)-E^{\circ}\left(\mathrm{Pb}^{2+} / \mathrm{Pb}\right)\right)+\frac{n F}{R T} \ln \left(\frac{K_{\mathrm{s}}(\mathrm{CuO})}{K_{\mathrm{s}}(\mathrm{PbO})}\right),
$$

where $K_{\mathrm{s}}(\mathrm{J})$ denotes the solubility product of the J-compound. Taking available thermochemical data for differing corrosion products, ${ }^{1}$ one obtains $K_{\text {eq }}>>1$ for the case, in which tenorite and litharge are the corrosion products. Then, for given equilibrium conditions, the ratio between the thermochemical activities of $\mathrm{CuO}$ and $\mathrm{PbO}, a_{\mathrm{CuO}} / a_{\mathrm{PbO}}$, which can be estimated from the peak current ratio in the voltammetric data, cab be given by 

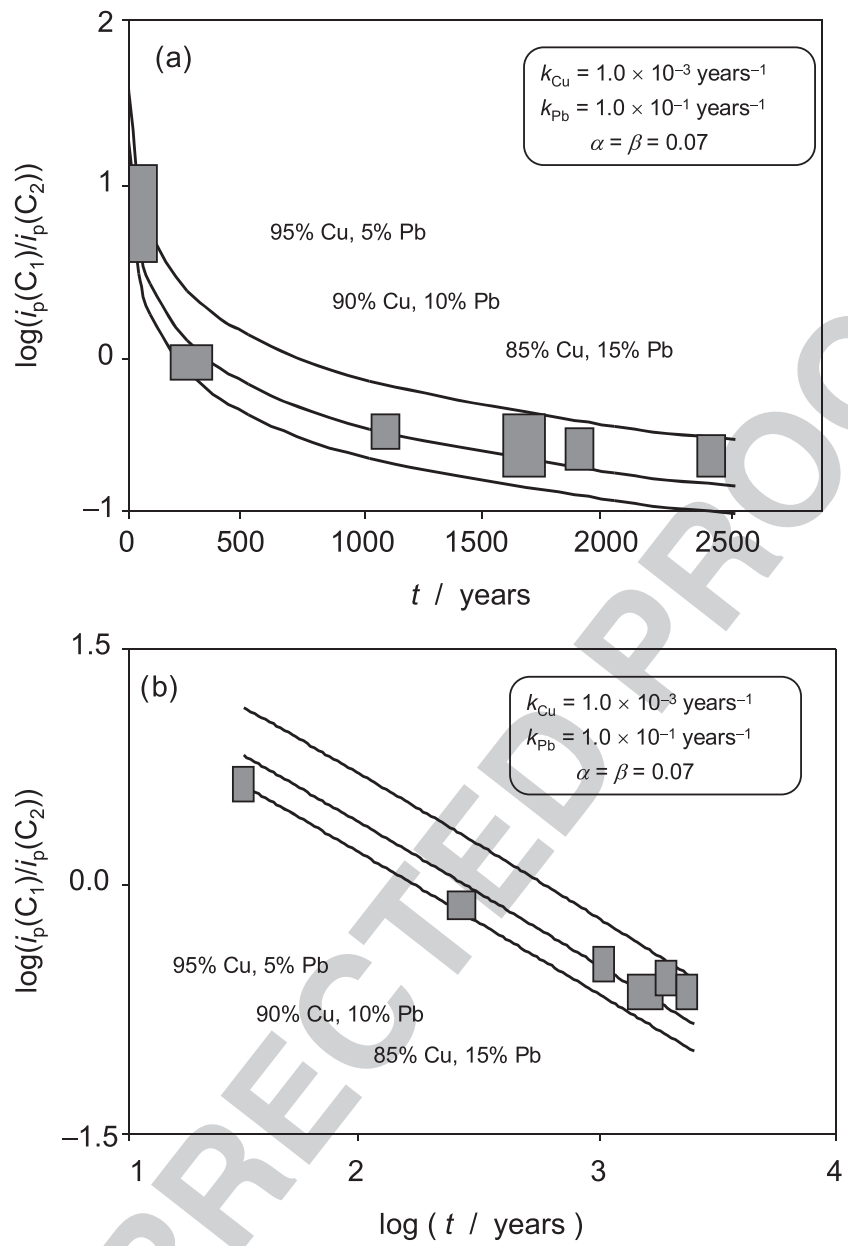

Figure 5 Theoretical lines for various selected compositions of leaded bronze, inserting $k_{\mathrm{Cu}}^{*}=1.0 \times 10^{-3}$ years ${ }^{-1}$ and $k_{\mathrm{Pb}}^{*}$ $=1.0 \times 10^{-1}$ years $^{-1}$ into equation $(11)$, and experimental data for the $\mathrm{i}_{\mathrm{p}}\left(\mathrm{C}_{1}\right) / \mathrm{i}_{\mathrm{p}}\left(\mathrm{C}_{2}\right)$ peak current ratio recorded in negative-going voltammograms for samples in this study using (a) semi-logarithmic and (b) double-logarithmic representations.

$$
\begin{gathered}
\ln \left(\frac{a_{\mathrm{CuO}}}{a_{\mathrm{PbO}}}\right)=\ln K_{\mathrm{eq}}+\ln \left(\frac{a_{\mathrm{Cu}}}{a_{\mathrm{Pb}}}\right), \\
\ln \left(\frac{a_{\mathrm{CuO}}}{a_{\mathrm{PbO}}}\right)=\frac{n F}{R T}\left(E^{\circ}\left(\mathrm{Cu}^{2+} / \mathrm{Cu}\right)-E^{\circ}\left(\mathrm{Pb}^{2+} / \mathrm{Pb}\right)\right)+\frac{n F}{R T} \ln \left(\frac{K_{\mathrm{s}}(\mathrm{CuO})}{K_{\mathrm{s}}(\mathrm{PbO})}\right)+\ln \left(\frac{a_{\mathrm{Cu}}}{a_{\mathrm{Pb}}}\right) .
\end{gathered}
$$

In the most favourable case, quasi-equilibrium conditions would be reached without extensive corrosion in the metallic phase(s), and the ratio between the thermochemical activities of the metals, $a_{\mathrm{Cu}} / a_{\mathrm{Pb}}$, could be approximated by the initial composition of the bronze. As a result, under quasi-equilibrium conditions for idealized corrosion, the net amount of lead corrosion products should be clearly larger than those of copper corrosion products, even for bronzes 
containing a low proportion of lead. Since the $i_{\mathrm{p}}\left(\mathrm{C}_{1}\right) / i_{\mathrm{p}}\left(\mathrm{C}_{2}\right)$ ratio is representative of the (copper corrosion products)/(lead corrosion products) ratio, the preceding thermochemical considerations are consistent with the record of low $i_{\mathrm{p}}\left(\mathrm{C}_{1}\right) / i_{\mathrm{p}}\left(\mathrm{C}_{2}\right)$ ratios for 'ancient' samples.

Following the literature on metal corrosion (Feliu and Morcillo 1982) and metal dating (Reich et al. 2003; Doménech-Carbó et al. 2011a, 2012, 2014, 2016b), the increase in the loading of Q6 corrosion products can be represented by a potential rate law. Although the modelling of the growth of corrosion layers on metal surfaces requires consideration of a variety of factors, electrochemical corrosion can be treated by considering that the rate of the oxygen reduction reaction equals the rate of metal oxidation (Venkatraman et al. 2011) and, in our case, equals Q7 the sum of the rates of oxidation of copper and lead. In the most simple approach, the surface concentration of corrosion products of a metal $\mathrm{M}, x_{\mathrm{M}}$, should satisfy a potential rate law of the form $\mathrm{d} x_{\mathrm{M}} / \mathrm{d} t=k_{\mathrm{M}} x^{-\delta}$, where $k_{\mathrm{M}}$ is the M-characteristic rate constant. Using the previously described simplified model for two-metal corrosion (Doménech-Carbó et al. 2012a), it will be assumed that a fine layer of the primary metal corrosion product (mainly cuprite and litharge) would be formed in this initial stage so that, depending on the corrosion conditions, a gross secondary patina of corrosion products grows progressively. Integration of the above generalized differential rate law yields

$$
x_{\mathrm{M}}=\left[X_{\mathrm{M}}^{1+\delta}+k_{\mathrm{M}}\right]^{1 /(1+\delta)},
$$

where $X_{\mathrm{M}}$ denotes the amount of primary corrosion product when the formation of the secondary corrosion layers is initiated. Accordingly, the ratio between the amounts of secondary corrosion products of copper and lead, which is the quantity accessible to the solid state voltammetric measurements, can be expressed as

$$
\frac{i_{\mathrm{p}}\left(\mathrm{C}_{1}\right)}{i_{\mathrm{p}}\left(\mathrm{C}_{2}\right)} \approx \frac{x_{\mathrm{Cu}}}{x_{\mathrm{Pb}}}=\frac{\left[X_{\mathrm{Cu}}{ }^{1+\alpha}+k_{\mathrm{Cu}} t\right]^{1 /(1+\alpha)}}{\left[X_{\mathrm{Pb}}{ }^{1+\beta}+k_{\mathrm{Pb}} t\right]^{1 /(1+\beta)}} .
$$

The relative uncertainty associated with the measurements of the peak current ratio, $\Delta\left[i_{\mathrm{p}}\left(\mathrm{C}_{1}\right) /\right.$ $\left.i_{\mathrm{p}}\left(\mathrm{C}_{2}\right)\right] /\left[i_{\mathrm{p}}\left(\mathrm{C}_{1}\right) / i_{\mathrm{p}}\left(\mathrm{C}_{2}\right)\right]$, can be expressed as a function of time, using the usual theory of error propagation, as

$$
\frac{\Delta\left(\frac{i_{\mathrm{p}}\left(\mathrm{C}_{1}\right)}{i_{\mathrm{p}}\left(\mathrm{C}_{2}\right)}\right)}{\left(\frac{i_{\mathrm{p}}\left(\mathrm{C}_{1}\right)}{i_{\mathrm{p}}\left(\mathrm{C}_{2}\right)}\right)}=\left(k_{\mathrm{Cu}}\left[X_{\mathrm{Cu}}{ }^{1+\alpha}+k_{\mathrm{Cu}} t\right]^{-1}-k P b\left[X_{\mathrm{Pb}}^{1+\beta}+k_{\mathrm{Pb}} t\right]^{-1}\right) \Delta t .
$$

Then, the relative uncertainty associated with age estimates, $\Delta t / t$, would be time-dependent:

$$
\frac{\Delta t}{t}=\frac{\Delta\left(\frac{i_{\mathrm{p}}\left(\mathrm{C}_{1}\right)}{i_{\mathrm{p}}\left(\mathrm{C}_{2}\right)}\right)}{\left(\frac{i_{\mathrm{p}}\left(\mathrm{C}_{1}\right)}{i_{\mathrm{p}}\left(\mathrm{C}_{2}\right)}\right)} \frac{1}{\left(\frac{k_{\mathrm{Cu}}}{X_{\mathrm{Cu}}{ }^{1+\alpha}+k_{\mathrm{Cu}} t}+\frac{k_{\mathrm{pb}}}{X_{\mathrm{Pb}}{ }^{1+\beta}+k_{\mathrm{pb}} t}\right) t} .
$$

Previous data on lead (Reich et al. 2003; Doménech-Carbó et al. 2011a) and copper (Doménech-Carbó et al. 2014) corrosion suggests that $\alpha \approx \beta \approx 0.07$, so that equation (8) can be approximated by 


$$
\frac{i_{\mathrm{p}}\left(\mathrm{C}_{1}\right)}{i_{\mathrm{p}}\left(\mathrm{C}_{2}\right)} \approx \frac{x_{\mathrm{Cu}}}{x_{\mathrm{Pb}}}=\frac{\left[X_{\mathrm{Cu}} / X_{\mathrm{Pb}}+k_{\mathrm{Cu}}^{*} t\right]^{0.93}}{\left[1+k_{\mathrm{Pb}}^{*} t\right]^{0.93}} .
$$

In this equation, $k_{\mathrm{Cu}}^{*}$ and $k_{\mathrm{Pb}}^{*}$ represent the $k_{\mathrm{Cu}} / X_{\mathrm{Pb}}$ and $k_{\mathrm{Pb}} / X_{\mathrm{Pb}}$ ratios. At time zero, equation (11) reduces to $x_{\mathrm{Cu}} / x_{\mathrm{Pb}}=X_{\mathrm{Cu}} / X_{\mathrm{Pb}}$, a ratio that can be assumed to be essentially identical to the composition of the alloy. Note that, as before, it is assumed that all other metals ( $\mathrm{Sn}, \mathrm{Zn}$ and $\mathrm{Sb})$ do not influence the voltammetric response of the copper and lead corrosion products. Figure 5 compares the theoretical curves using equation (11) for various compositions of leaded bronze, taking $k_{\mathrm{Cu}}^{*}=1.0 \times 10^{-3}$ years $^{-1}$ and $k_{\mathrm{Pb}}^{*}=1.0 \times 10^{-1}$ years $^{-1}$, with the experimental data (represented as error rectangles, including the extreme values for the differing samples from the same archaeological site) for the $i_{\mathrm{p}}\left(\mathrm{C}_{1}\right) / i_{\mathrm{p}}\left(\mathrm{C}_{2}\right)$ peak current ratio recorded in negative-going voltammograms previously described using the baselines depicted in Figure 2. Here, semilogarithmic (Fig. 5 (a)) and double-logarithmic (Fig. 5 (b)) scales have been depicted in order to facilitate the comparison between the different theoretical lines at short and long times, respectively.

A comparison of the theoretical calibration curves using equation (11) with the experimental data in Figure 5 suggests that although there is a relatively large uncertainty in age estimates and there is a relatively large dispersion in the values of the $i_{\mathrm{p}}\left(\mathrm{C}_{1}\right) / i_{\mathrm{p}}\left(\mathrm{C}_{2}\right)$ ratio, there is no inconsistency between them. In these circumstances, such data can be considered as potentially usable for dating leaded bronze of unknown age under favourable conditions.

It should be emphasized that the corrosion response of metallic artefacts is extremely sensitive to the environment, so that the extent and type of corrosion can vary significantly from one sample to another or even in different regions of the same sample. It is also pertinent to note that lead extraction can occur as dendrite or interdendritically, and there are cases where all the lead inclusions have been fully converted to cuprite or redeposited copper. The reported methodology can be considered as applicable under a specific set of conditions, limited here to samples moderately corroded under atmospheric/soil in the Mediterranean region. Its extension to other corrosion conditions-in particular, gross corrosion with the formation of thick layers, and corrosion in marine environments - is problematic and has to be assessed in future research.

The proposed methodology can be viewed as a complementary tool that can be used to characterize leaded bronze archaeological objects and provide information about their age. It is pertinent to underline that an appropriate calibration is required and that this is valid only for a specific set of corrosion conditions. Due to the aforementioned limitations, the resolution in age estimates provided by the reported methodology was relatively low, increasing with the corrosion time (see Fig. 5) to uncertainties between \pm 250 to \pm 500 years at the end of the period of time (fourth to second century BC and 20th century AD) covered in this study. Although a detailed knowledge of the composition and properties of each object via elemental and metallographic analyses is needed for a complete study of archaeological pieces, the proposed methodology can be considered as potentially useful to complement existing techniques because of: (i) the simplicity and versatility of voltammetric measurements; (ii) the requirement for non-invasive sampling, limited to the corrosion products; and (iii) the possibility of easy in-field sampling and transportation for laboratory measurements. 


\section{CONCLUSIONS}

The electrochemical responses, using the voltammetry of immobilized particles methodology, of samples from the corrosion layers of leaded bronze objects in contact with aqueous acetate buffer consisted mainly of signals due to copper and lead corrosion products, which were consistent with the known occurring processes of destannification and dezincation. Several yoltammetric features can be considered as indicative of prolonged corrosion: (i) cathodic signatures of $\mathrm{Pb}(\mathrm{IV}$ ) and 'porous' $\mathrm{PbO}$; (ii) low ratios between the intensities of cathodic signals for copper corrosion products and lead corrosion products; and (iii) low ratios between the intensities of stripping signals for copper and lead oxidative dissolution. A theoretical modelling was proposed to describe the relationship between the intensity of the signals of the copper and lead corrosion products, the composition of the original alloy and the corrosion time, using a potential rate law. Experimental data for samples from statuary from the Roman archaeological sites of Valeria and El Viveret (Spain) and a set of weights from the Roman site of Gadara (Jordan), accompanied by modern statuary exhibited outdoors, on the campus of the Universitat Politècnica of Valencia, Spain, were found to be consistent with that theoretical model within the tested time interval (fourth to second century BC and 20th century AD).

\section{ACKNOWLEDGMENTS}

Financial support from the MINECO Projects CTQ2014-53736-C3-1-P and CTQ2014-53736C3-2-P, which are supported by ERDF funds, is gratefully acknowledged. We wish to thank the Fondo de Arte y Patrimonio of the Universitat Politècnica de València; the Museu de Prehistòria of València, and its director Helena Bonet and curator Jaime Vives-Ferrándiz; and the Museu Municipal of Xàtiva and its director Angel Velasco. We also wish to thank Dr José Luis Moya López and Mr Manuel Planes Insausti (Microscopy Service of the Universitat Politècnica de València) for technical support.

\section{REFERENCES}

Arjmand, F., and Adriaens, A., 2012, Electrochemical quantification of copper-based alloys using voltammetry of microparticles: optimization of the experimental conditions, Journal of Solid State Electrochemistry, 16(2), 535-43.

Attanasio, D., Bultrini, G., and Ingo, G. M., 2001, The possibility of provenancing a series of bronze Punic coins found at Tharros (western Sardinia) using the literature lead isotope database, Archaeometry, 43, 529-47.

Blum, D., Leyffer, W., and Holze, R., 1996, Pencil-leads as new electrodes for abrasive stripping voltammetry, Electroanalysis, 8(3), 296-7.

Bouchard, M., and Smith, D. C., 2003, Catalogue of 45 reference Raman spectra of minerals concerning research in art history of archaeology, especially on corroded metal and coloured glass, Spectrochimica Acta A, 59(10), $2247-66$.

Cai, W. -B., Wan, Y. -Q., Lu, H. -T., and Zhou, W. -F., 1995, A study of the reduction process of anodic $\mathrm{PbO}_{2}$ film on $\mathrm{Pb}$ in sulfuric acid solution, Journal of Electroanalytical Chemistry, 387(1-2), 95-100.

Chase, W. T., 1994, Chinese bronzes: casting, finishing, patination and corrosion, in Ancient \& historic metals: conservation and scientific research: proceedings of a symposium organized by the J. Paul Getty Museum and the Getty Conservation Institute, November 1991 (eds. D. A. Scott, J. Podany, and B. Consodine), 86-117, Getty Conservation Institute, Marina del Rey, CA.

Chiavari, C., Rahmouni, K., Takenouti, H., Joiret, S., Vermaut, P., and Robbiola, L., 2007, Composition and electrochemical properties of natural patinas of outdoor bronze monuments, Electrochimica Acta, 52(27), 7760-9.

Constantinides, I., Adriaens, A., and Adams, F., 2002, Surface characterization of artificial corrosion layers on copper alloy reference materials, Applied Surface Science, 189(1-2), 90-101.

Costa, V., and Urban, F., 2005, Lead and it alloys: metallurgy, deterioration and conservation, Reviews in Conservation, International Institute of Conservation, 6(1), 48-62.

Costa, V., Leyssens, K., Adriaens, A., Richard, N., and Scholz, F., 2010, Electrochemistry reveals archaeological materials, Journal of Solid State Electrochemistry, 14(3), 449-51. 
Cura D'Ars de Figueiredo, J. Jr., de Freitas Cunha Lins, V., and De Bellis, V. M., 2007, Surface characterization of a corroded bronze-leaded alloy in a salt spray cabinet, Applied Surface Science, 253(17), 7104-7.

De Ryck, I., Adriaens, A., Pantos, E., and Adams, F., 2003, A comparison of microbeam techniques for the analysis of corroded ancient bronze objects, Analyst, 128(8), 1104-9.

Doménech-Carbó, A., 2010, Voltammetric methods applied to identification, speciation and quantification of analytes from works of art: an overview, Journal of Solid State Electrochemistry, 14(3), 363-9.

Doménech-Carbó, A., and Doménech-Carbó, M. T., 2005, Electrochemical characterization of archaeological tinopacified lead-alkali glazes and their corrosion processes, Electroanalysis, 17(21), 1959-69.

Doménech-Carbó, A., Doménech-Carbó, M. T., and Costa, V., 2009, Electrochemical methods in archaeometry, conservation and restoration, Springer-Verlag, Berlin.

Doménech-Carbó, A., Doménech-Carbó, M. T., and Martínez-Lázaro, I., 2008, Electrochemical identification of bronze corrosion products in archaeological artefacts: a case study, Microchimica Acta, 162(3-4), 351-9.

Doménech-Carbó, A., Doménech-Carbó, M. T., and Martínez-Lázaro, I., 2010, Layer-by-layer identification of copper alteration products in metallic works of art using the voltammetry of microparticles approach, Analytica Chimica Acta, 610(1), 1-9.

Doménech-Carbó, A., Doménech-Carbó, M. T., and Peiró-Ronda, M. A., 2011a, Dating archaeological lead artifacts from measurement of the corrosion content using the voltammetry of microparticles, Analytical Chemistry, 83(14), 563944.

Doménech-Carbó, A., Doménech-Carbó, M. T., and Peiró-Ronda, M. A., 2011b, 'One-touch' voltammetry of microparticles for the identification of corrosion products in archaeological lead, Electroanalysis, 23(12), 1391-400.

Doménech-Carbó, A., Labuda, J., and Scholz, F., 2013, Electroanalytical chemistry for the analysis of solids: characterization and classification (IUPAC technical report), Pure and Applied Chemistry, 85(3), 609-31.

Doménech-Carbó, A., Doménech-Carbó, M. T., Lastras, M., and Herrero, M., 2015, Detection of archaeological forgeries of Iberian lead plates using nanoelectrochemical techniques: the lot of fake plates from Bugarra (Spain), Forensic Science International, 247(1), 79-88.

Doménech-Carbó, A., Doménech-Carbó, M. T., Pasíes, T., and Bouzas, M. C., 2011c, Application of modified Tafel analysis to the identification of corrosion products on archaeological metals using voltammetry of microparticles, Electroanalysis, 23(12), 2803-12.

Doménech-Carbó, A., Doménech-Carbó, M. T., Pasíes, T., and Bouzas, M. C., 2012a, Modeling corrosion of archaeological silver-copper coins using the voltammetry of immobilized particles, Electroanalysis, 24(10), $1945-55$.

Doménech-Carbó, A., Doménech-Carbó, M. T., Peiró-Ronda, M. A., and Osete-Cortina, L., 2011d, Authentication of archaeological lead artifacts using voltammetry of microparticles: the case of the Tossal de Sant Miquel Iberian plate, Archaeometry, 53, 1193-211.

Doménech-Carbó, A., Doménech-Carbó, M. T., Capelo, S., Pasíes, T., and Martínez-Lázaro, I., 2014, Dating archaeological copper/bronze artifacts using the voltammetry of microparticles, Angewandte Chemie International Edition, 53(35), 9262-6.

Doménech-Carbó, A., Doménech-Carbó, M. T., Peiró-Ronda, M. A., Martinez-Lázaro, I., and Barrio, J., 2012b, Application of the voltammetry of microparticles for dating archaeological lead using polarization curves and electrochemical impedance spectroscopy, Journal of Solid State Electrochemistry, 16(7), 2349-56.

Doménech-Carbó, A., Doménech-Carbó, M. T., Redondo-Marugán, J., Osete-Cortina, L., and Vivancos-Ramón, M. V., 2016a, Electrochemical characterization of corrosion products in leaded bronze sculptures considering ohmic drop effects on Tafel analysis, Electroanalysis, 28(4), 833-45.

Doménech-Carbó, A., Capelo, S., Piquero, J., Doménech-Carbó, M. T., Barrio, J., Fuentes, A., and Al-Sekkaneh, W., 2016b, Dating archaeological copper using electrochemical impedance spectroscopy. Comparison with voltammetry of microparticles dating, Materials and Corrosion, 67(2), 120-9.

Donate Carretero, I., Medina Sánchez, M. C., Faieta, R., Barrio Martín, J., Doménech-Carbó, A., Fuentes Domínguez, A., Pardo Naranjo, A. I., and Martínez Zapata, O., 2015, Estudio interdisciplinar de pátinas en esculturas romanas de bronce procedentes del yacimiento de Valeria (Cuenca), in MetalEspaña 2015, II Congreso de Conservación y Restauración del Patrimonio Metálico, Segovia, 1-3 de Octubre de 2015, Universidad Autónoma de Madrid.

Feliu, S., and Morcillo, M., 1982, Atmospheric corrosion testing in Spain, in Atmospheric corrosion (ed. W. H. Allor), 913-21, Wiley, New York.

Formigli, E., Ferro, D., and Bovani, S., 2006, La patina artificiale antica dei grandi bronzi di Ercolano, KERMES: la rivista del restauro, 19(1), 29-34.

Formigli, E., Lahusen, G., and Ferro, D., 2005, Note di storia del restauro archeologico: i restauri settecenteschi ai grandi bronzi di Ercolano, KERMES: la rivista del restauro, 18(1), 35-48. 
Frost, R. L., 2003, Raman spectroscopy of selected copper minerals of significance in corrosion, Spectrochimica Acta A, 59(6), 1195-204.

Fuentes, A., and Escobar, R., 2013, El edificio de la curia en el foro de Valeria, in Las sedes de los 'Ordines decurionum' en Hispania: análisis arquitectónico y modelo tipológico, Anejos de archivo Español de arqueología LXVII, 215-30, Instituto de Arqueología, Mérida.

Gettens, R. J., 1969, The Freer Chinese bronzes, Smithsonian Institution and Freer Gallery of Art, Washington, DC.

Hughes, M. J., Northover, J. P., and Staniaszek, B. E. P., 1982, Problems in the analysis of leaded bronze alloys in ancient artefacts, Oxford Journal of Archaeology, 3(3), 359-64.

Ingo, G. M., Plescia, P., Angelini, E., Riccucci, C., and De Caro, T., 2006, Bronze Roman mirrors: the secret of brightness, Applied Physics A, 83(4), 611-15.

Leoni, M., Diana, M., Guidi, G., and Pierdominici, F., 1991, Sul fenomeno della destannazione dei manufatti bronzei di provenienza archeologica, La Metallurgia Italiana, 83(11), 1033-7.

McCann, L. I., Trentleman, K., Possley, T., and Golding, B., 1999, Corrosion of ancient Chinese bronze money trees studied by Raman microscopy, Journal of Raman Spectroscopy, 30(2), 121-32.

Meeks, N. D., 1986, Tin-rich surfaces on bronze-some experimental and archaeological considerations, Archaeometry, 28, 133-62.

Nair, M. T. S., Guerrero, L., Arenas, O. L., and Nair, P. K., 1999, Chemically deposited copper oxide thin films: structural, optical and electrical characteristics, Applied Surface Science, 150(1-4), 143-51.

Ottenwelter, E., and Costa, V., 2015, Evidence of metallic plating on archaeological artefacts by voltammetry of microparticles, Archaeometry, 57, 497-504.

Pavlov, D., Monakhov, B., Maja, N., and Penazzi, N., 1989, Mechanism of action of Sn on the passivation phenomena in the lead-acid battery positive plate (Sn-free effect), Journal of the Electrochemical Society, 136(1), 27-33.

Pavlov, D., Monakhov, B., Salmi, K., and Sundholm, G., 1991, Ring-disk electrode studies of soluble intermediates formed during the polarization of $\mathrm{Pb}$ in $\mathrm{H}_{2} \mathrm{SO}_{4}$, Electrochimica Acta, 36(5-6), 953-63.

Pernicka, E., 1998, Whither metal analysis in archaeology? in L'atelier du bronzier en Europe du XXe au VIIIe siècle avant notre ère, Bronze'96, Tome I (eds. C. Mordant, M. Pernot, and V. Rychner), 259-67, Comité des Travaux Historiques et Scientifiques, Paris.

Quaranta, M., Catelli, E., Prati, S., Sciutto, G., and Mazzeo, R., 2014, Chinese archaeological artefacts: microstructure and corrosion behaviour of high-leaded bronzes, Journal of Cultural Heritage, 15(3), 283-91.

Reich, S., Leitus, G., and Shalev, S., 2003, Measurement of corrosion content of archaeological lead artifacts by their Meissner response in the superconducting state; a new dating method, New Journal of Physics, 5, 99.1-9-.

Robbiola, L., and Hurtel, L.-P., 1997, Standard nature of the passive layers of buried archaeological bronze-the example of two Roman half-length portraits, in Metal 95: proceedings of the International Conference on Metals Conservation, Semur en Auxois, 25-28 September 1995 (eds. I. MacLeod, S. Pennec, and L. Robbiola), 109-17, James \& James, London.

Robbiola, L., and Portier, R., 1998, Electron microscopy and EDX analysis in the investigation of the decuprification phenomena in CuSn alloys: a comparison between archaeological and synthetic bronzes, in Electron microscopy, 1998: proceedings of the 14th International Congress on Electron Microscopy, Cancún (Mexico), 31 August to 4 September 1998 (eds. H. A. Calderón Benavides and M. J. Yacamán), 289-90, Vol. III, Institute of Physics Publishing, Bristol.

Robbiola, L., and Portier, R., 2006, A global approach to the authentication of ancient bronzes based on the characterization of the alloy-patina-environment system, Journal of Cultural Heritage, 7(1), 1-2.

Robbiola, L., Blengino, J. -M., and Fiaud, C., 1998, Morphology and mechanisms of formation of natural patinas on archaeological CuSn alloys, Corrosion Science, 40(12), 2083-111.

Sandu, I., Marutoiu, C., Sandu, I. G., Alexandru, A., and Sandu, A. V., 2006, Authentication of old bronze coins I: study on archaeological patina, Acta Universitatis Cibinensis, Seria F: Chemia, 9(1), 39-53.

Satovic, D., Martinez, S., and Bobrowski, A., 2010, Electrochemical identification of corrosion products on historical and archaeological bronzes using the voltammetry of micro-particles attached to a carbon paste electrode, Talanta, 81(45), 1760-5.

Scholz, F., and Meyer, B., 1998, Voltammetry of solid microparticles immobilized on electrode surfaces, in Electroanalytical chemistry, a series of advances, 20(1) (eds. A. J. Bard and I. Rubinstein), 1-86, Marcel Dekker, New York.

Scholz, F., Schröder, U., Gulaboski, R., and Doménech-Carbó, A., 2014, Electrochemistry of immobilized particles and droplets, 2nd edn, Springer-Verlag, Berlin.

Scott, D. A., 1994, An examination of the patina and corrosion morphology of some Roman bronzes, Journal of the American Institute for Conservation, 33(1), 1-23. 
Scott, D. A., 1997, Copper compounds in metals and colorants: oxides and hydroxides, Studies in Conservation, 42(2), 93-100.

Scott, D. A., 2000, A review of copper chlorides and related salts in bronze corrosion and as painting pigments, Studies in Conservation, 45(1), 39-53.

Scott, D. A., 2002, Copper and bronze in art: corrosion, colorants and conservation, II, Getty Conservation Institute, Los Angeles, CA.

Selwyn, L., 2004, Metals and corrosion: a handbook for the conservation professional, 122-3, Canadian Conservation Institute, Ottawa.

Serghini-Idrissi, M., Bernard, M. C., Harrif, F. Z., Joiret, S., Rahmouni, K., Srhiri, A., Takenouti, H., Vivier, V., and Ziani, M., 2005, Electrochemical and spectroscopic characterizations of patinas formed on an archaeological bronze coin, Electrochimica Acta, 50(24), 4699-709.

Souissi, N., Bousselmi, L., Khosrof, S., and Triki, E., 2004, Voltammetric behaviour of an archaeological bronze alloy in aqueous chloride media, Materials and Corrosion, 55(4), 284-92.

Venkatraman, M. S., Cole, I. S., and Emmanuel, B., 2011, Model for corrosion of metals covered with thin electrolyte layers: pseudo-steady state diffusion of oxygen, Electrochimica Acta, 56, 7171-9.

Weisser, T. S., 1975, The de-alloying of copper alloys, in Conservation in archaeology and the applied arts, Preprints of the contributions to the Stockholm Congress, 2-6 June 1975, 207-14, International Institute for Conservation.

Welter, J.-M., 2003, The zinc content of brass: a chronological indicator, Techné, 18(1), 27-36.

Zakharchuk, N., Meyer, S., Lange, B., and Scholz, F., 2000, A comparative study of lead oxide modified graphite paste electrodes and solid graphite electrodes with mechanically immobilized lead oxides, Croatica Chemica Acta, 73(3), 667-704. 


\section{Author Query Form}

\section{Journal: Archaeometry}

\section{Article: arcm_12308}

Dear Author,

During the copyediting of your paper, the following queries arose. Please respond to these by annotating your proofs with the necessary changes/additions.

- If you intend to annotate your proof electronically, please refer to the E-annotation guidelines.

- If you intend to annotate your proof by means of hard-copy mark-up, please use the standard proofing marks. If manually writing corrections on your proof and returning it by fax, do not write too close to the edge of the paper. Please remember that illegible mark-ups may delay publication.

Whether you opt for hard-copy or electronic annotation of your proofs, we recommend that you provide additional clarification of answers to queries by entering your answers on the query sheet, in addition to the text mark-up.

\begin{tabular}{|c|c|c|}
\hline Query No. & Query & Remark \\
\hline Q1 & $\begin{array}{l}\text { AUTHOR: Please confirm that given names (red) and } \\
\text { surnames/family names (green) have been identified } \\
\text { correctly. }\end{array}$ & \\
\hline Q2 & $\begin{array}{l}\text { AUTHOR: AUTHORS: Please check that citations of } \\
\text { "Robbiola and Portier 1998" and "Robbiola et al. 1998" } \\
\text { are correct throughout. }\end{array}$ & \\
\hline Q3 & $\begin{array}{l}\text { AUTHOR: The citation "Scholz and Mayer (1998)" has } \\
\text { been changed to "Scholz and Meyer (1998)" to match } \\
\text { the author name/date in the reference list. Please check } \\
\text { if the change is fine in this occurrence and modify the } \\
\text { subsequent occurrences, if necessary. }\end{array}$ & \\
\hline Q4 & $\begin{array}{l}\text { AUTHOR: AUTHORS: Should this read 2016a or } \\
\text { 2016b? }\end{array}$ & \\
\hline Q5 & $\begin{array}{l}\text { AUTHOR: Figures are assumed to be colour online only. } \\
\text { If you would like it to appear in colour both in print and } \\
\text { online, please complete and return a colour work } \\
\text { agreement form. Please download this from http:// } \\
\text { onlinelibrary.wiley.com/journal/10.1111/(ISSN)1475- } \\
\text { 4754/homepage/ARCM_CWA_Form_2015.pdf }\end{array}$ & \\
\hline
\end{tabular}




\begin{tabular}{|c|l|c|} 
Query No. & \multicolumn{1}{|c|}{ Query } & Remark \\
\hline Q6 & $\begin{array}{l}\text { AUTHOR: AUTHORS: Should this read 2012a or } \\
\text { 2012b? }\end{array}$ & \\
\hline Q7 & $\begin{array}{l}\text { AUTHOR: AUTHORS: Please check this reference in } \\
\text { detail. See the reference list. }\end{array}$ & $\begin{array}{l}\text { AUTHOR: AUTHORS: The following reference does } \\
\text { not seem to be cited in the text and has been removed } \\
\text { from the list:Wang, Q., and Merkel, J. F., 2001, Studies } \\
\text { on the redeposition of copper in Jin bronzes from } \\
\text { Tianma-Qucun, Shanxi, China, Studies in Conservation, } \\
\text { 46(4), 242-50. }\end{array}$ \\
\hline
\end{tabular}




\section{WI LEY \\ Online Proofing System}

1. Corrections should be marked with the Adobe Annotation \& Comment Tools below:

http://wiley-black...qTrJcH\&user=author +

(7) wiley-blackwell.spi-global.com/authorproofs/journal/onlineproofs/index2.php?id=vOgLEvVsdvuzhoT03112014205007IVpecDjWzqTrJcH\&user=author

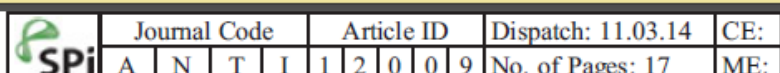

\section{Race, Waste, and Space: Brownfield Redevelopment and Environmental}

2. To save your proof corrections, click the 'Publish Comments' button. Publishing your comments saves the marked up version of your proof to a centralized location in Wiley's Online Proofing System. Corrections don't have to be marked in one sitting - you can publish corrections and log back in at a later time to add more.

3. When your proof review is complete we recommend you download a copy of your annotated proof for reference in any future correspondence concerning the article before publication. You can do this by clicking on the icon to the right of the 'Publish Comments' button and selecting 'Save as Archive Copy...'.

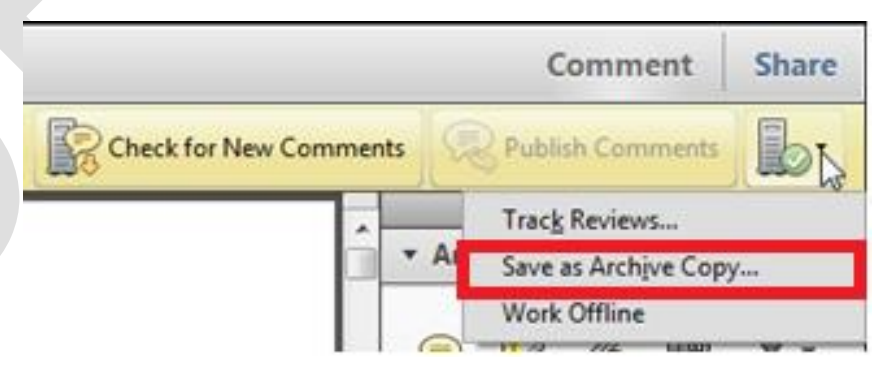

4. When your proof review is complete and you are ready to send corrections to the publisher click the 'Complete Proof Review' button that appears above the proof in your web browser window. Do not click the 'Complete Proof Review' button without replying COMPLETE PROOF REVIEW to any author queries found on the last page of your proof. Incomplete proof reviews will cause a delay in publication. Note: Once you click 'Complete Proof Review' you will not be able to mark any further comments or corrections.

\section{Enabling Adobe PDF Viewer}

If your PDF article proof opens in any browser PDF viewer other than Adobe Reader or Adobe Acrobat, you will not be able to mark corrections and query responses, nor save them. Please follow these instructions to enable Adobe Reader or Acrobat as the default browser PDF viewer in Internet Explorer, Firefox, and Safari so the PDF article proof opens in a browser window. 